doi:10.18575/msrs.sm.e.16.15

UDK 616.314-089.23

COBISS.RS-ID 6162968

\title{
Changes on the Soft Tissues of the Oral Cavity during the Orthodontic Treatment Depending on the Type of Orthodontic Appliance
}

\begin{abstract}
Introduction : Periodontal status and malocclusions are closely related. Retention places that enable for detention of food caused by various malocclusions, make selfcleaning and proper hygiene difficult and as such endanger the integrity of the soft tissues. Correctly applied orthodontic treatment has positive effects on periodontal tissues as it reduces the risk of damage and inflammations. One of the key factors for successful orthodontic therapy is adequate maintaining of the oral hygiene, which includes removal of dental plaque, the main cause of deterioration of the soft tissues of the oral cavity.
\end{abstract}

\section{Aim of the study:}

- Establish the connection between changes in the soft tissues of the oral cavity and the type of used orthodontic appliance.

- Establish the time interval for appearance of changes on the soft tissues of the oral cavity.

Patients and Methods: This research included 120 patients who were divided into three groups depending on the type of the orthodontic appliance used (mobile orthodontic appliance - active, mobile orthodontic appliances - functional and fixed orthodontic appliances). Examinations were performed three times: at the beginning of the treatment, after three months of therapy and after six months of therapy. In order to analyze the status of the soft tissues of the oral cavity and level of hygiene we used: Silness-Löe plaque index and Löe-Silness gingival index.

Results: In patients divided by the type of orthodontic therapy, a statistically significant difference in the value of indexes after three and six months of wearing orthodontic appliances was found in patients who wore fixed orthodontic appliances. There was a difference in increased index values among this group when compared to subjects treated with mobile orthodontic appliances.

Conclusion: During the orthodontic therapy, especially with fixed orthodontic appliances, patients must pay attention to adequate oral hygiene maintenance in order to avoid any unwanted changes on soft tissues of the oral cavity.

Key words: orthodontic malocclusions, oral hygiene, gingival index, plaque index.

(Scr Med 2016:47:88-93)

\section{Marijana Arapović Saviće ${ }^{\text {, }}$ Mirjana Umićević Davidović, Adriana Arbutina, Marija Obradović ${ }^{2}$, Igor Đukić ${ }^{3}$}

${ }^{1}$ Department of Orthodontics, Study
Program Dentistry, Faculty of
Medicine, University of Banja Luka,
Banja Luka, Bosnia and Herzegovina
${ }^{2}$ Department of Pediatric Dentistry,
Study Program Dentistry, Faculty of
Medicine, University of Banja Luka,
Banja Luka, Bosnia and Herzegovina
${ }^{3}$ Department of Oral Surgery, Study
Program Dentistry, Faculty of
Medicine, University of Banja Luka,
Banja Luka, Bosnia and Herzegovina

Contact address:

Marijana Arapović-Savić,

Save Mrkalja 4.

$780 o o$ Banja Luka,

Republic of Srpska

Bosna and Hercegovina

E-mail: as.marijana@gmail.com

Telephone: +387-65-670-232.
Submitted:April 12 $2^{\text {th }}, 2016$ Accepted: April 25, 2016

\section{Introduction}

Orthodontic treatment reflects on the whole state of the dentoalveolar structures, as well as on the complete health status of the patient. Correct positioning of the teeth significantly reduces the chances for the development of caries and parodontal ailments, while outward appearance that is achieved by the end of the treatment contributes to the improved mental health and restores patient's selfconfidence. ${ }^{1,2}$ 
Establishing the habit of correct hygiene maintenance during the orthodontic therapy, regardless of the therapy type, whether it is fixed or mobile, is of paramount importance for preservation of hard and soft tissues of the oral cavity, success of the orthodontic treatment and retaining of the achieved results. The patients have to be informed about the importance of maintaining of the oral health in great detail.

Dental plaque is created on all surfaces of the teeth but it accumulates only on those areas that are not exposed to self-cleaning during eating. Those areas are: parts of the teeth next to free gingiva and gingival sulcus, approximal contact, i.e. interdental areas between the teeth, as well as other parts that are not reached by hard and sharp food. In order to remove the dental plaque it is necessary to use the correct toothbrush and to educate the patient on proper technique of teeth brushing. ${ }^{3}$

Efficient removal of dental plaque and following the instructions received from the therapist regarding the proper hygiene maintenance are key success factors for orthodontic treatment. ${ }^{4-6}$

More difficult maintaining of the oral hygiene necessitates additional instructions and explanations to the patients regarding how and what instruments to use to efficiently remove the dental plaque. It is also essential to provide constant motivation and support to the patients. During the orthodontic treatment, especially fixed one, it is significant to use preventive programs with the aim of improving the oral hygiene quality. ${ }^{7-9}$

\section{Aim of the Study:}

- Establish the connection between changes in the soft tissues of the oral cavity and the type of used orthodontic appliance.

- Establish the time interval for appearance of changes on the soft tissues of the oral cavity.

\section{Patients and Methods}

This research included 120 patients of both sexes, ages 12 to 20. All patients had permanent dentition. In accordance with regulations on protection of personal data, all data was anonymized. Patients were divided into three groups depending on the type of appliance used in the therapy:

- First group consisted of 40 patients wearing mobile appliances - active.

- Second group consisted of 40 patients wearing mobile removable - functional.

- Third group consisted of 40 patients wearing fixed orthodontic appliances.

The dental examinations were performed under day light using the flat mirror, dental probes and parodontal probe. Collected data was entered into custom made forms, separately for every patient. Examinations were performed three times: at the first examination and three and six months after the start of the therapy. The research was conducted at Dental office of "Dom zdravlja" Banja Luka and private dental practice "Astrodens" Banja Luka in 2012.

In order to assess the state of the soft tissues of the oral cavity as well as the level of the oral hygiene, the following indexes were used:

1. Silness-Löe plaque index.

2. Löe-Silness gingival index.

Silness-Löe plaque index is used to establish the thickness of the dental plaque and not how widespread it is. Examined surfaces include gingival thirds of vestibular, oral, distal and mesial surfaces of the tooth crown. It is possible to examine all or just the representative teeth.

Representative teeth and surfaces that are examined are:

1. vestibular surface of upper right first molar.

2. vestibular surface of upper right first incisor.

3. vestibular surface of upper left first molar.

4. lingual surface of lower left first molar.

5. vestibular surface of lower left first incisor.

6. lingual surface of lower right first molar.

Prior to determining of this index, the patient should rinse the teeth thoroughly and teeth to be examined are to be dried by air flow. Plaque index of a person is calculated by adding all the values, ranging from 0 to 3 , for each of the examined teeth after which the sum is divided by the number of examined teeth.

Dental plaque index is determined by following criteria: index o means that there is no plaque on the gingival third of the tooth crown; index 1 denotes a thin film of plaque at the edge of gingiva and on the surface of the tooth adjoining it, it is not visible by the naked eye, it is exposed by using the probe on the aforementioned area; index 2 means that there is a moderate amount of plaque that is now visible by unaided eye, there are deposits on the edge of gingiva, on the surface of the tooth adjoining it, but also in gingival sulcus; index 3 denotes significant amount of dental plaque 
that covers the edge of gingiva, surface of adjoined tooth and fills the gingival sulcus.

Löe-Silness gingival index is the index most widely used to establish the status of gingiva. By using this index we can assess the state of gingiva on the vestibular, oral, mesial and distal side of the tooth. The assessment is based on the changes in the color, swelling and bleeding of gingiva.

Index o denoted healthy gingiva, the gingiva is pale pink in color, firm and has fine-grained surface. Papilla are contained in the interdental area and do not protrude outside of it. The shape of the papilla depends on the position of the teeth. Index 1 denoted slight inflammation, the edge of gingiva is more reddish than normal. There is a slight edema and increased emitting of gingival exudate. Gingiva is not bleeding when gently provoked by blunt dental probe. Moderate inflammation is marked by index 2 and is represented by gingiva that is red. There is a significant edema and enlarged free gingiva. Bleeding occurs on gentle pressure by the probe. Strong inflammation is marked by index 3 , the gingiva is very red and enlarged. There is a tendency for spontaneous bleeding. There are also ulcerations on the gingiva.

Total gingival index is obtained by adding together all values established for all four sides of present teeth and then divided by four. This value is further divided by the number of teeth. Patients with index values below 1 have slight inflammation of gingiva, while values between 1 and 2 indicate moderate gingival inflammation. Average values between 2 and 3 suggest severe inflammation of the gingiva.

For the statistical analysis of the data we used standard descriptive statistics such as: mean value and standard deviation, as needed. In order to compare differences between the groups of the patients we used ANOVA (Analysis of Variance). Statistically significant difference was accepted to exist when the $\mathrm{p}$ was less than 0.05 $(\mathrm{p}<0.05)$.

All the relevant results were presented in tabular and graphical form by using corresponding type of diagram. For statistical analysis, preparation and presentation of the data we used following software: R v2.12, OpenOffice and Microsoft Office.

\section{Results of the Research}

Plaque index

After three months of wearing orthodontic appliances we have found statistically significant differences in values of plaque index, when compared to initial values, based on the type of the appliance used in the therapy. Mean values of plaque index after three month of the therapy were 0.16 for active appliances, 0.20 for functional appliances and 0.50 for fixed appliances. After performing ANOVA analysis we established values of $\mathrm{F}=14.11$ and $\operatorname{Pr}(>\mathrm{F})<0.00001$ which suggests statistically significant difference. Mean values and standard deviations are presented on the Image 1.

With patients grouped by the type of orthodontic therapy, after six months of the therapy, significantly higher mean values for plaque index were found with the patients wearing the fixed orthodontic appliances (0.60) when compared to patients wearing active (0.19) and functional (o.26) appliances. ANOVA analysis of plaque index values after six months of the therapy produced $\mathrm{F}=20.02$ and $\operatorname{Pr}(>\mathrm{F})<0.00001$ which suggests statistically significant difference for three types of the therapy.

Image 1. Mean values and standard deviations of plaque index change after three months of therapy

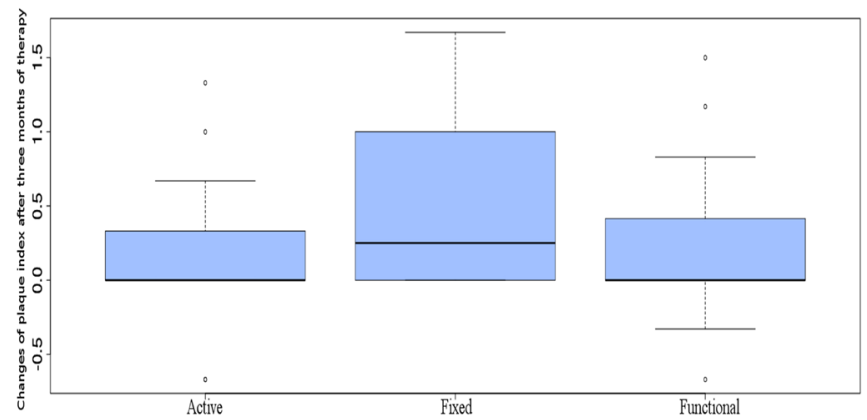

With patients grouped by the type of orthodontic therapy after six months, statistically significant differences were found with patients wearing fixed orthodontic appliances with significantly higher mean values of dental plaque index when compared to patients wearing mobile appliances. Mean values and standard deviations are given in Image 2.

Image 2. Mean values and standard deviations of plaque index change after six months of therapy

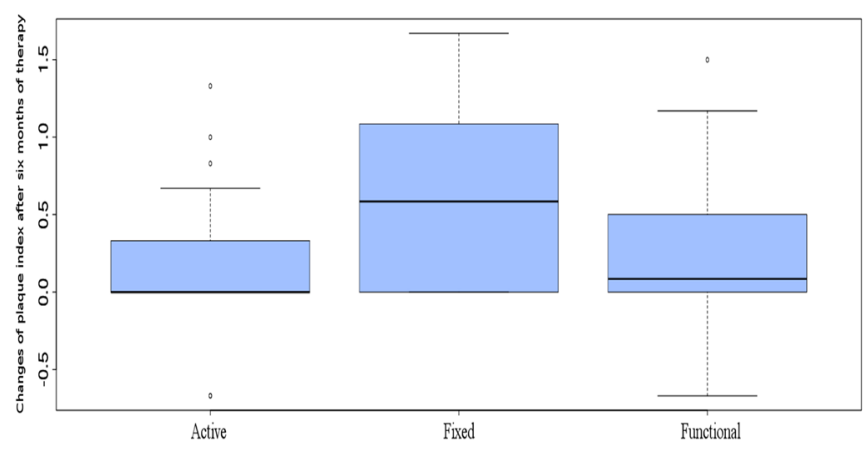

Gingival index

By examining the values of the gingival index after three months of the orthodontic therapy, with patients grouped 
by the type of the appliance worn, higher mean values were found at patients wearing the fixed orthodontic appliances (0.52) when compared to patients wearing active (o.12) and functional (0.23) appliances. Obtained differences were statistically significant (ANOVA $F=16.36$ and $\operatorname{Pr}(>\mathrm{F})<0.00001)$. Mean values and standard deviations are presented in Image 3.

Image 3. Mean values and standard deviations of gingival index change after three months of therapy

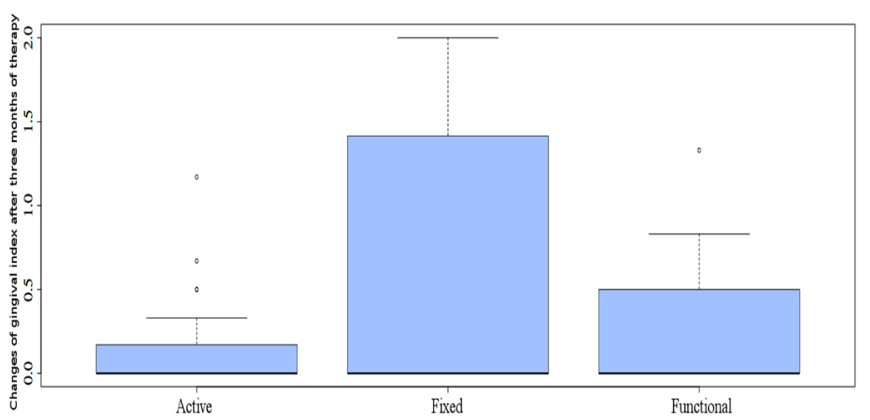

Six months after the start of the therapy, we measured the gingival index values again. Mean value of the gingival index in group of the patients wearing the fixed orthodontic appliances was found to be 0.65 , while patients wearing active appliances were found to have 0.16 and functional appliances 0.28 change in mean value. The differences were established to be statistically significant (ANOVA F $=23.74$ and $\operatorname{Pr}(>\mathrm{F})<0.00001)$. Mean values and standard deviations are given in Image 4.

Image 4. Mean values and standard deviations of gingival index change after six months of therapy

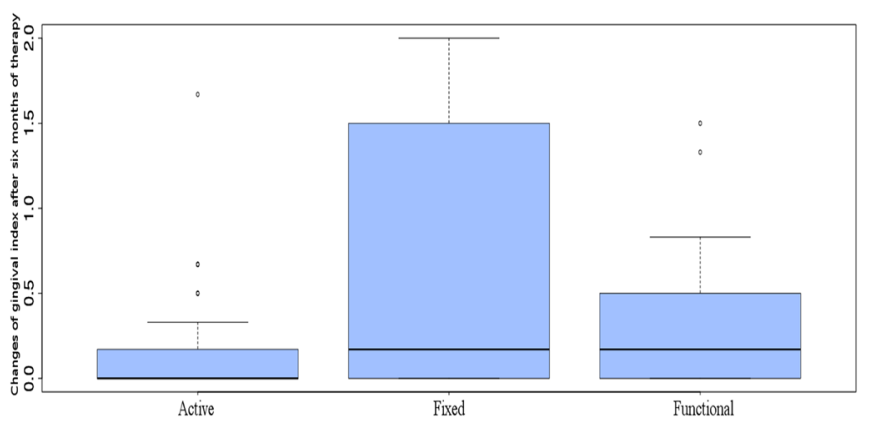

By examining the obtained values of gingival index after six months of the orthodontic therapy with patients grouped by the type of orthodontic appliance used, there was a statistically significant difference and increased mean values of gingival index in the group of patients wearing the fixed orthodontic appliances when compared with patients wearing mobile orthodontic appliances.

\section{Discussion}

Orthodontic treatment enables for establishing of the proper function of occlusion, and through that improved oral health, but it also carries with it an increased risk of introducing damage to the soft tissues of the oral cavity if the patient does not rigorously follow the instructions of the orthodontist, especially regarding the oral hygiene. Establishing the habit of maintaining of the proper oral hygiene during the course of the orthodontic treatment, regardless of the type of the treatment, is of paramount importance for preservation of the soft tissues of the oral cavity as well as for success of the orthodontic treatment and retaining of the achieved results. ${ }^{7}$

By utilizing adequate oral hygiene, the patients can successfully prevent accumulation of the dental plaque. The therapist has to, above all, motivate the patients to properly maintain the oral hygiene, train them in choosing a correct dental brush and using it afterwards, i.e. to apply the correct technique of teeth brushing and control them to make sure they really do utilize it. ${ }^{3}$

By analyzing the results obtained in this research, we have noted the statistically significant difference between the groups of the patients grouped by the type of appliance used. Increased values of plaque and gingival index after three and six months of wearing of the orthodontic appliance were found in patients wearing the fixed orthodontic appliances when compared to patients wearing mobile appliances. Increased values are likely the consequence of inadequate level of oral hygiene as well as wearing the appliances that further complicate maintaining the oral hygiene. Obtained results are in accordance with a number of authors that covered this issue. ${ }^{10-13}$

A large number of studies have shown the lack of adequate hygiene during the orthodontic treatments, which in turn had as a consequence appearance of ailment of the soft tissues of the oral cavity during the therapy. ${ }^{14-17}$

Marić, Čupić and Vukić-Ćulafić found that plaque index was $78.94 \%$ in patients undergoing the orthodontic treatment. After the education on proper maintaining of the oral hygiene, after two months control period, plaque index was reduced to $41.83 \%$. There is a need for a more frequent motivating of the patients for proper maintaining of the oral hygiene as well as longer term activities of all health workers with the aim of reducing of accumulation of dental plaque and reduction in new caries lesions and lower incidence of gingival inflammations. ${ }^{15}$

Matić, Ivanović and Nikolić have shown that establishing a habit of proper hygiene maintaining during the orthodontic therapy, regardless of the type of the therapy, is of great 
importance for preservation of soft and hard tissues of the oral cavity and for the success of the orthodontic treatment, as well as for preserving the results of the therapy. ${ }^{17}$

Studies performed by Liu and associates have shown that fixed orthodontic therapy in large number of cases provides ample ground for increased deposits of dental plaque and gingivitis, as they observed significant increase in plaque and gingival index even after three months of orthodontic therapy. Same studies have shown that due to simpler maintaining of the oral hygiene and smaller number of retention places, the status of gingiva was much better in patients wearing mobile orthodontic appliances when compared with patients wearing fixed orthodontic appliances. ${ }^{18}$

Radlinska and associates, as well as Pietrzak and associates have concluded in their studies that the proper maintaining of the oral hygiene, with the right training and motivation during the mobile orthodontic therapy does not introduce deterioration of soft tissues of the oral cavity. 19,20

Research performed by Gomes and associates has shown that there are no ill effects of orthodontic therapy, mobile or fixed, if the patients follow instructions received from orthodontists about proper maintaining of the oral hygiene. 10 Their results are in accordance with the results obtained by Skold Larsson and associates in 2003 as well as Perinetti and associates in 2004. ${ }^{11,21}$

In comparative study carried out by Bollen and associates, studies exploring the effect of orthodontic therapy on parodontal tissues published in six different journals in the period from 1980 to 2006 were examined. The studies have shown that in patients undergoing the orthodontic treatment, there was gingival recession of $0.03 \mathrm{~mm}, 0.13$ $\mathrm{mm}$ loss of alveolar bone and $0.23 \mathrm{~mm}$ of increase of the depth parodontal pockets when compared to control group. The existing evidence suggests that orthodontic treatment has small ill effects on parodontal tissues if the patients adhere to instructions received from therapists. ${ }^{12}$

\section{Conclusion}

- Changes on gingiva during the orthodontic therapy are more frequent in therapy with fixed orthodontic appliances.

- Examining the presence and the amount of the dental plaque after three and six months of dental therapy shows increase in levels of dental plaque, especially in patients wearing fixed appliances.

\section{Reference}

1. Graber LW, Vanarsdall Jr RL, Vig KW. Orthodontics: current principles and techniques. Elsevier Health Sciences.
2011 Jul 14.

2. Proffit WR, Fields Jr HW, Sarver DM. Contemporary orthodontics. Elsevier Health Sciences. 2014 Mar 12.

3. Đajić D, Đukanović D, Kojović D. Bolesti usta - Oralna medicina i parodontologija. Elit medica, Beograd. 2008; 214-237.

4. Boyd RL, Murray P, Robertson PB. Effect of rotary electric toothbrush versus manual toothbrush on periodontal status during orthodontic treatment. American Journal of Orthodontics and Dentofacial Orthopedics. 1989 Oct 31;96(4):342-7.

http://dx.doi.org/10.1016/0889-5406(89)90354-5

5. Mueller LJ, Darby ML, Allen DS, Tolle SL. Rotary electric toothbrushing. Clinical effects on the presence of gingivitis and supragingival dental plaque. Dental hygiene. 1987 Dec;61(12):546.

6. Casey GR. Maintenance of oral hygiene and dental health during orthodontic therapy. Clinical preventive dentistry. 1988;10(1):11.

PMid:3272858

7. Matić S, Ivanović M, Nikolić P. Procena efikasnosti preventivnih programa za pacijente sa fiksnim ortodontskim aparatima. Vojnosanitetski pregled. 2011;68(3):214-9.

8. Fenlon MR, McCartan BE. Medical status of patients attending a primary care dental practice in Ireland. Journal of the Irish Dental Association. 1990 Dec;37(3-4):75-7.

9. Ljušković B, Ivić N, Kardašević I. Najefikasnije metode za održavanje oralne higijene pacijenata sa fiksnim ortodontskim aparatima. Stomatološki informator. 2011;17(28):13-5.

10. Gomes SC, Varela CC, Da Veiga SL, Rösing CK, Oppermann RV. Periodontal conditions in subjects following orthodontic therapy. A preliminary study. The European Journal of Orthodontics. 2007 Oct 1;29(5):477-81. http://dx.doi.org/10.1093/ejo/cjmo5o PMid:17693428

11. Sköld-Larsson K, Yucel-Lindberg T, Twetman S, Modéer T. Effect of a triclosan-containing dental gel on the levels of prostaglandin I2 and interleukin-1 $\beta$ in gingival crevicular fluid from adolescents with fixed orthodontic appliances. Acta Odontologica Scandinavica. 2003 Jan 1;61(4):193-6.

http://dx.doi.org/10.108o/ooo16350310003242 PMid:14582585

12. Bollen AM, Cunha-Cruz J, Bakko DW, Huang GJ, Hujoel PP. The effects of orthodontic therapy on periodontal health: a systematic review of controlled evidence. The Journal of the American Dental Association. 2008 Apr 30;139(4):413-22. http://dx.doi.org/10.14219/jada.archive.2008.0184 PMid:18385025

13. Heuer W, Elter C, Demling A, Neumann A, Suerbaum S, Hannig M, Heidenblut T, Bach FW, Stiesch-Scholz M. Analysis of early biofilm formation on oral implants in man. Journal of oral rehabilitation. 2007 May 1;34(5):37782. http://dx.doi.org/10.1111/j.1365-2842.2007.01725.x PMid:17441878

14. Demling A, Heuer W, Elter C, Heidenblut T, Bach FW, 
Schwestka-Polly R, Stiesch-Scholz M. Analysis of supraand subgingival long-term biofilm formation on orthodontic bands. The European Journal of Orthodontics. 2009 Apr 1;31(2):202-6.

http://dx.doi.org/10.1093/ejo/cjno9o

PMid:19304761

15. Ljaljević A, Matijević S, Terzić N, Anđelić J, Mugoša B. Značaj održavanja oralne higijene za zdravlje usta i zuba. Vojnosanitetski pregled. 2012 Jan;69(1):16-22.

16. Marić D, Čupić S, Vukić-Ćulafić B. Higijena usta u dece koja se ortodontski leče. Stomatološki glasnik Srbije. 1982; 29(2): 349-352.

PMid:6964703

17. Matić S, Ivanović M, Nikolić P. Procena efikasnosti preventivnih programa za pacijente sa fiksnim ortodontskim aparatima. Vojnosanitetski pregled. 2011;68(3):214-9.
18. Liu H, Sun J, Dong Y, Lu H, Zhou H, Hansen BF, Song $\mathrm{X}$. Periodontal health and relative quantity of subgingival Porphyromonas gingivalis during orthodontic treatment. The Angle orthodontist. 2011 Feb 9;81(4):609-15.

http://dx.doi.org/10.2319/082310-352.1

PMid:21306224

19. Radlińska J. The condition of periodontium in children treated with removable orthodontic devices. Czasopismo stomatologiczne. 1990 Mar;43(3):165-8. PMid:2104342

20. Pietrzak P, Śmiech-Słomkowska G. Evaluation of oral hygiene using $\mathrm{OHI}$ in patients treated with removable appliances. Czas. Stomatol. 2009;62(9):728-34.

21. Perinetti S, Barbato E, Simonetti DA. Effect of orthodontic therapy with fixed and removable appliances on oral microbiota: a six-month longitudinal study. The new microbiologica. 1997 Jan;20(1):55-62.

\section{Promjene na mekim tkivima usne duplje u toku ortodontske terapije u zavisnosti od vrste ortodontskog aparata}

\section{SAŽETAK}

Uvod: Parodontalna oboljenja su usko povezana sa malokluzijama. Retenciona mjesta za zadržavanje hrane, nastala kao posljedica pojedinih malokluzija, otežavaju samočišćenje i pravilno održavanje oralne higijene i tako ugrožavaju integritet mekih tkiva. Pravilno spovedena ortodontska terapija ima pozitivne učinke na parodontalna tkiva jer smanjuje mogućnost nastanka oštećenja i upala. Jedan od ključnih faktora za uspješnu ortodontsku terapiju je adekvatno održavanje oralne higijene, a samim tim i uklanjanje dentalnog plaka, glavnog uzročnika oštećenja mekih tkiva usne duplje.

\section{Cilj rada:}

- Utvrditi zavisnost pojedinih promjena na mekim tkivima usne duplje u odnosu na vrstu korištenog ortodontskog aparata.

- Utvrditi vremenski interval nastanka promjena na mekim tkivima usne duplje.

Ispitanici i metode: $\cup$ ovo istraživanje je bilo uključeno 120 pacijenata, podijeljenih u tri grupe, u zavisnosti od vrste korištenog ortodontskog aparata (mobilni ortodontski aparat-ploča, mobilni funkcionalni aparat-aktivator i fiksni ortodontski aparat). Pregledi su obavljeni tri puta: na početku terapije, te nakon tri i šest mjeseci nošenja ortodontskog aparata. Za analizu stanja mekih tkiva usne duplje i nivoa oralne higijene korišteni su: Plak indeks po Silness-Löe-u i Gingivalni indeks po Löe Silness-u.

Rezultati: Kod ispitanika podijeljenih prema vrsti ortodontske terapije, statistički značajna razlika u vrijednostima indeksa, nakon tri i šest mjeseci nošenja ortodontskog aparata, nađena je kod ispitanika koji su nosili fiksne ortodontske aparate. Razlika se manifestovala u povišenim vrijednostima indeksa kod ove grupe u odnosu na grupe pacijenata koji su nosili mobilne ortodontske aparate.

Zaključak: $U$ toku ortodontske terapije, a naročito fiksne, pacijenti moraju posvetiti pažnju adekvatnom održavanju oralne higijene da bi se izbjegle neželjene promjene na mekim tkivima usne duplje.

Ključne riječi: ortodontske nepravilnosti, oralna higijena, gingivalni indeks, plak indeks 